Бердник В. П., доктор ветеринарних наук, професор, Тімченко О. В., здобувач

Полтавська державна аграрна академія

\title{
ПОРІВНЯННЯ РЕЗУЛЬТАТІВ ДОСЛІДЖЕНЬ МОЛОКА КОРІВ ІЗ ДОПОМОГОЮ МАСТИДИНОВОЇ ПРОБИ ТА КУЛЬТУРАЛЬНОГО МЕТОДУ НА ВИДІЛЕННЯ STAPHYLOCOCCUS AUREUS
}

\section{Рецензент - доктор біологічних наук С. В. Гапон}

\begin{abstract}
У порівняльному аспекті наведені результати досліджень 85-и проб молока корів із застосуванням мастидинової проби і культурального методу на виділення Staphylococcus aureus. 3 допомогою мастидинової проби одержали позитивні результати в 20 (23,5\%) випадків, а культурального методу34 (40,0\%). Із 41 проби молока об 'ємом 10,0 мл ізолювали культури St. aureus у 34 (82,9\%) випадках, 1,0 мл-у $25(61,0 \%)$ i 0,1 мл - у 22 (53,6\%) випадках. У 13 (65,0\%) із 20 проб молока, які реагували із мастидином, результати обох тестів співпали, в семи $(35,0 \%)-н і$.
\end{abstract}

Ключові слова: коров'яче молоко, золотистий стафілокок, мастидин, токсикози.

Постановка проблеми. Молоко є цінних харчовим продуктом для людини і незамінним кормом для молодняку тварин. Його якість у значній мірі залежить від ступеня забруднення бактерійною флорою ендогенного (запалення молочних залоз) та екзогенного походження (порушення умов утримання, годівлі та догляду; санітарногігієнічних умов отримання й первинної переробки молока; люди-носії стафілококів тощо) [1]. Нерідко молоко стає джерелом бактерій, небезпечних для здоров'я людей, до яких відноситься й умовно-патогенний Staphylococcus (St.) aureus.

Роль молока і молочних продуктів у виникненні стафілококових токсикозів постійно зростає, досягаючи нині понад $30 \%$ від числа всіх випадків масових токсикозів людей, передусім дітей [4]. Відомо близько 30 хвороб, збудники яких можуть передаватися через молоко [2]. Вони досить поширені й спричинюють значні економічні збитки, викликані проведенням діагностичних досліджень і лікуванням хворих людей, а в тваринництві - через зменшення продуктивності тварин, їх загибель тощо.

Аналіз останніх досліджень i публікацій, у яких започатковано розв'язання проблеми. У загальній кількості бактеріальних харчових отруєнь стафілококові токсикози поступаються лише сальмонельозним токсикоінфекціям. Роль стафі- лококів у виникненні харчових токсикозів почали вивчати із 40-х років XX століття [Б. Л. Бамм, 1942; К. I. Туржецький, 1955; А. С. Baird-Parker, 1960, 1965; А. Ф. Білібін, 1962; Е. А. Нечаева, 1965; А. К. Акатов, 1976; В. М. Івченко, 1985 й ін.].

Стафілококові отруєння, що викликаються ендотоксинами ентеротоксигенних культур St. aureus, досить небезпечні для людей. Для накопичення в молоці ентеротоксину в небезпечній для людини дозі необхідно мати в ньому не менше 500 тис. $/ \mathrm{cm}^{3}$ клітин ентеротоксигенних стафілококів і його температуру близько $20{ }^{\circ} \mathrm{C}$ протягом шести годин.

У молоці, що зберігається протягом декількох годин після видоювання (сирому), ентеротоксин накопичується рідко тому, що воно досить швидко піддається охолодженню й через антагоністичну дію на стафілококи інших бактерій, які є в ньому [2]. Тому стафілококові отруєння людей частіше $\epsilon$ наслідком вживання молочних продуктів, які забруднюються St. aureus під час їх виготовлення [4].

Мікрофлора довкілля постійно проникає в молочну залозу корови через соскові канали $[1,4]$. Основна іiі маса знищується факторами неспецифічного захисту молочної залози, але частина з них, зокрема, St. aureus, виживає й бере участь у розвитку маститів [4]. Такі патогенні стафілококи продукують ентеротоксини групи А і В, які й викликають отруєння людей, особливо дітей [5].

Мета дослідження - порівняти результати досліджень молока мастидиновою пробою для виявлення прихованого маститу у корів, а також культуральним методом на виділення культур золотистого стафілокока.

Матеріали і методики дослідження. Для досліджень відібрали 85 проб сирого молока, яке зберігали за температури $18-20{ }^{\circ} \mathrm{C}$ не більше 4-7 годин після видоювання. Пробу з мастидином ставили згідно 3 описаною методикою [1]. St. aureus виявляли 3 допомогою бактеріологічного методу у пробах молока об'ємом 10 мл, 
1,0 мл і 0,1 мл відповідно до прийнятих методик $[3,6]$. Для цього застосували елективний сольовий бульйон, жовтково-сольовий агар та агар Байрд Паркера. В ході ідентифікації збудника ставили також тести на наявність ферментів каталази, ДНК-ази і коагулази, збродження глюкози, маніту і мальтози в анаеробних умовах 3 утворенням кислоти та альфа- і бета-гемолізу на кров'яному агарі [1].

Результати досліджень. У 41 (48,2\%) із 85 досліджених проб молока одержали позитивні результати в обох тестах, що наведено в таблиці.

Із даних таблиці видно, що з допомогою мастидинової проби одержали позитивні результати в $20(23,5 \%)$ випадків із 85 досліджених проб молока, а культурального методу - 34 (40,0 \%). До того ж із 41 проби молока об'ємом 10,0 мл ізолювали культури St. aureus у 34 (82,9 \%) випадках, 1,0 мл - 25 (61,0 \%) і 0,1 мл - 22 (53,6 \%) випадках. У $13(65,0 \%)$ із 20 проб молока, які реагували із мастидином, результати обох тестів співпали, в семи $(35,0 \%)-$ ні.

3 іншого боку, в 21 (51,2 \%) із 41 випадку з позитивними результатами щодо виділення St. aureus не одержали реакції із мастидином. У процесі мікроскопії мазків із культур St. aureus на предметному склі спостерігали грампозитивні коки, які розміщувались у вигляді кисті винограду чи плодів смородини, як це зображено на рисунку.

Виділені культури коків володіли лецитиназною активністю щодо плазми крові кроля, розкладали глюкозу, маніт і мальтозу в анаеробних умовах, викликали деполімеризацію ДНК й мали жовтий пігмент. Їх віднесли до роду Staphylococcus, виду aureus (золотистий). Із 49 проб молока ізолювали також культури St. epidermidis, які не мали ферменту коагулази, не розкладали глюкозу і маніт. У частині випадків культури коків були в асоціації 3 стрептококами та диплококами.

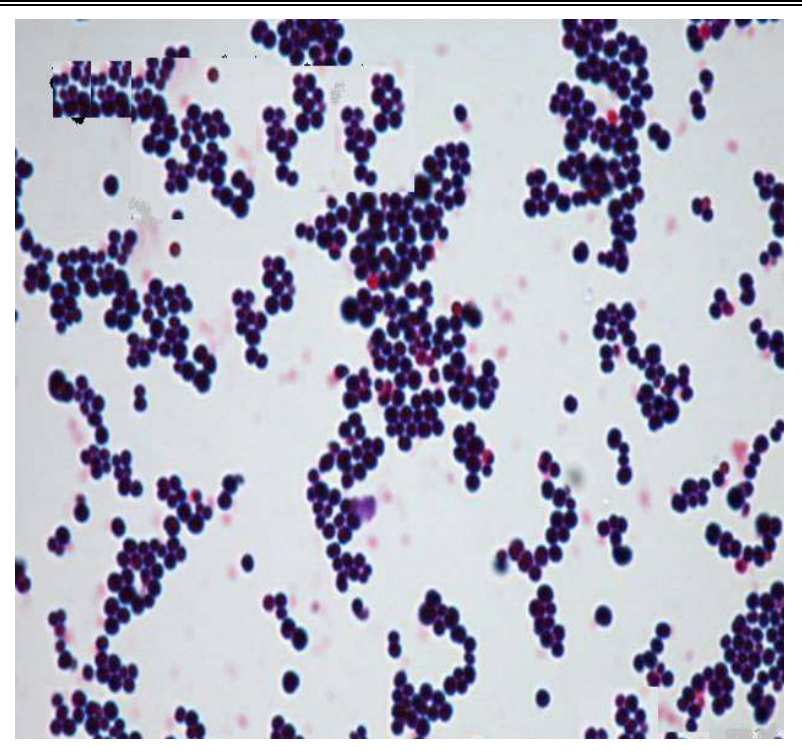

Рис. Мазок на предметному склі з агарової культури St. aureus. 3б. х 675.

Розбіжність результатів застосування мастидинової проби і культурального методу, ймовірно, $\epsilon$ наслідком того, що з їх допомогою виявляють різні сторони забруднення молока. Мастидинова проба показує процес зміни якості молока через запальний процес у молочній залозі. 3 допомогою культурального методу виявляється значно більше джерел забруднення молока бактеріями, в тому числі i St. aureus - із ураженої запаленням молочної залози, під час доїння, зберігання й транспортування, тобто через контакт із посудом і руками працівників молокопереробних підприємств. Культуральний метод - значно чутливіший для індикації рівня забруднення молока бактеріями, передусім у дослідженні його проби в об'ємах у межах 1,0-10,0 мл.

Слід враховувати, що в числі збудників маститів y корів (окрім St. aureus) можуть бути й ентеробактерії, стрептококи, зокрема, Streptococcus agalactiae тощо [1].

Порівняння результатів досліджень 41 проби молока за допомогою тесту з мастидином та культурального методу на виділення St. aureus

\begin{tabular}{|c|c|c|c|c|c|}
\hline \multirow{2}{*}{$\begin{array}{c}\text { Проба } \\
\text { з мастидином }\end{array}$} & \multicolumn{2}{|c|}{ Бактеріологічне дослідження проб } & \multicolumn{2}{c|}{ Варіанти результатів } \\
\cline { 2 - 6 } & 10,0 & 1,0 & 0,1 & абс. число & $\%$ \\
\hline+ & + & + & + & 12 & 29,3 \\
\hline+ & + & - & - & 1 & 2,4 \\
\hline+ & - & - & - & 7 & 17,1 \\
\hline- & + & + & + & 10 & 24,4 \\
\hline- & + & + & - & 3 & 7,3 \\
\hline- & + & - & - & 8 & 19,5 \\
\hline 20 & 34 & 25 & 22 & 41 & 100,0 \\
\hline
\end{tabular}

Примітка: + - результат позитивний ; - - негативний 


\section{Висновки:}

1. У $41(48,2 \%)$ iз 85 досліджених проб молока одержали позитивні результати в обох тестах. У тесті з мастидином реагувало $20(23,5 \%)$ із 85 проб молока, a St. aureus виділили із них у 34 $(40,0 \%)$ випадках. Позитивні результати обох тестів співпали в 65,0 \% випадків; були лише із мастидином у $35,0 \%$, тільки в культуральному методі - в 51,2 \% випадків.

\section{БІБЛІОГРАФІЯ}

1. Бердник В. П., Аранчій С. В., Бердник I. Ю. [ma iн.]. Методичні рекомендації щодо діагностики, профілактики субклінічного маститу корів та боротьби з ним. - Полтава, 2005. - 54 с.

2. Ветеринарно-санітарна експертиза $з$ основами стандартизації продуктів / О. М. Якубчак, В. І. Хоменко, С. Д. Мельничук [та ін.]. - К., 2005. - 800 с. 3. Инструкция о порядке расследования учета и проведения лабораторных исследований в учреждениях санитарно-эпидемиологической службы при пищевых отравлениях №1 135-73.

4. Касянчук В., Крижанівський Я. Основні закономірності обсіменіння молока золотистим стафілококом // Ветеринарна медицина України. -
2. St. aureus $є$ одним із збудників маститу у корів і продуцентом ентеротоксинів у забрудненому ним молоці, не охолодженому відразу після видоювання.

3. Для попередження токсикозів проби підозрілого молока й продуктів із нього об'ємом не менше 1,0-10,0 мл треба досліджувати на виявлення St. aureus культуральним методом.

№10, 2003. - C. 43-45.

5. Методические рекомендации. Лабораторная диагностика стафилококковых инфекций / Ивченко В. М. - Кишинев : Тимнул, 1980. -20 с.

6. Мікробіологія харчових продуктів і кормів для тварин. Готування досліджуваних проб, вихідної суспензії та десятикратних розведень для мікробіологічного дослідження. - Ч. 1. - Загальні правила готування вихідної суспензії та десятикратних розведень. - ДСТУ ISO 6887-1:2003.

7. Минор T. E., Mapm E. X. Стафилококки в пищевых продуктах / Перевод с англ. Н. С. Королевой с соавт. - М. : Пищевая промышленность, 1980. $-232 \mathrm{c}$. 